\title{
Affixes and Tone in Aguata Igbo: A Critical Appraisal
}

\author{
Chinwe E. Obianika \\ Department of Linguistics and Literary Studies, Ebonyi State University, Abakaliki.
}

\begin{abstract}
This work sets out to investigate the behavior of tone in the affixes involved in the formation of three aspects in Aguata Igbo. The dialect group comprises of three main dialects; Amaiyi, Orumba and Aguata. Three respondents are selected to represent each dialect. The data are collected through personal interview and analyzed descriptively to find out how these aspects are realized in each dialect to ascertain their level of similarities and differences. In the findings, there are variations both in the affixes and in the tone patterns indicating that they are different (though related) dialects of the Igbo language, contrary to popular notion that they all speak the same dialect.
\end{abstract}

Keywords: dialect, verb forms, tone, aspect, Igbo language

\section{INTRODUCTION}

Aguata is a geographical area that was mapped out as an administrative area in the pre-independent Nigeria and became a local government area during the Obasanjo regime of the 1970s. It is bounded on the north and west by the old Njikoka Local Government Area of Anambra State and on the east by Okigwe Local Government Area of Imo State. There are about forty nine autonomous communities that make up this region. They include but not limited to Ụmụuchu, Achina, Mkpologwu, Akpo, Enugwu-Ụmụọnỵa, Agbụdụ, Amesi, Ưmụọmakụ, Ụmụalaọma, Ekwuluọbịa, Oko, Isuọfịa, Igboukwu, Agụlụezechukwu, Nanka, Ụga, Ezinifite, Ưmụọna, Ikenga, One, Awgbụ, Ufuma, Ajali and so on.

There are three distinct dialects in Aguata which every speaker in the area recognizes. It is usually easy to say which of these dialect areas a speaker comes from by the person's speech. Presently, the area is divided into three local government areas namely; Aguata, Orumba North and Orumba South Local Government Areas but they do not correspond to these dialect areas because they overlap. However, an earlier structuring of the Aguata geographical area into three local government areas by a civilian administration in 1981 corresponds more to the traditional and dialectal structuring and naming. The three areas are known traditionally as Aguata, Amaiyi and Orumba. Aguata dialect is spoken in towns such as Oko, Ekwuluọbịa, Isuọfịa, Igboukwu, Agụlụezechukwu, Nanka, Ụga, Ezinifite, Ụmụọna, Ikenga, One and Awgbụ. Oko represents this dialect in this work. Amaiyi dialect, for this work is represented by Akpo. The towns under this dialect include Umụuchu, Achịna, Nkpologwu, Akpo, Enugwu-Ụmụọnyịa, Agbụdụ, Amesi, Ụmụọmakụ and Ụmụalaọma. Orumba dialect is spoken in these towns; Ufuma, Ajalị, Isulo, Ndịkeliọnwụ, Ndịowuu, Amaọkpala, Ụmụnze, Ihite, Ogbunka, Owere-Ezukala, Nkerefi, Awa, Ndịukwuenu, Ezira, Nawfija, Akpụ, Eziagụ and Ndịokpalaeze. These towns are represented by Umụnze in this analysis. These dialects are related and have a degree of minor similarities. These notwithstanding, there exists enough variations that keep them as distinct dialects. In this analysis, we chose to ignore these minor differences and concentrate on the major ones.

The study of affixation in Igbo centers on the verb as it is the only category that accepts inflectional affixes in the language. This analysis therefore is based on the Igbo verb. There are two types of affixes in Igbo; the derivational and the inflectional but we will handle only the inflectional affixes in this work.

1.2 Objectives: This research sets out to investigate the interaction between tone and inflectional affixes in Igbo dialects of Aguata to find out the behavior of tone and the similarities and differences within the dialects in the realization of the different aspects and tense in these dialects. The result is then used to ascertain the truth or otherwise of the notion that the Aguata communities speak one dialect.

\section{METHODOLOGY}

The data for the analysis are gathered through personal interview with the respondents selected from the three dialects under study; two males and two female adult L1 speakers for each dialect. Simple sentences in the different tenses are presented to each respondent in Standard Igbo. They are then asked to translate them into their respective dialects. The answers are then recorded with a notebook and on a tape recorder. The analysis is carried out descriptively.

2.1 Affixes: Affixes are bound morphemes that are attached to words. The process of attaching affixes is called affixation. It is a morphological process of adding affixes to stems/roots to modify, extend or change the 
meaning or function of the word (Nwankwegu 2013). There are two types based on their function; derivational and inflectional. Derivational affixes bring about a change in meaning and word class of the words to which they are affixed inflectional affixes do not involve any change of meaning or word class. Examples of affixes in English include -ness (kindness), -dom (kingdom), -er (teacher), -ful (careful), -ly (gladly), -ation (formation), hood (manhood) and -mal (maltreat) ( Ndimele 2007).

In Igbo as stated earlier, affixation affects only verbs as this is the only word class that accepts affixation in the language. Both processes of derivation and inflection occur in Igbo but for this work, only the inflectional affixes will be considered. Verbs are inflected for both tense and aspect in Igbo. We are also going to investigate the behavior of tone in the products of affixation in Aguata Igbo.

2.2 Tone: According to Katamba (1989), pitch is the extent to which a sound is high or low. The height of pitch is dependent on the tautness of the vocal cords and the rate of vibration of the vocal cords. The tauter the vocal cords are, the faster they vibrate and the higher the pitch perceived and vice versa. Pitch is used in two significant ways in language; it is either used at the level of the syllable as tone to mark contrastive differences in words and mark grammatical functions in tone languages or utilized in higher units (such as phrases, clauses and sentences) to mark intonation and other functions in intonation languages (Ashby and Maidment (2005). Pike (1948) defines a tone language as one having a lexically significant, contrastive but relative pitch on each syllable. On the other hand, Yip (2007) quoting Hyman (2001) defines a tone language as one in which an indication of pitch enters into lexical realization of at least some morphemes. By these definitions of tone, we infer that tone forms a part of every syllable and consequently contributes in the distinctive elements of every word in a tone language. Since tone is distinctive in a tone language, it forms part of the basis for the delineation of dialects as its use varies according to dialects though still within the limits of intelligibility.

2.3 Dialect is a variety of a language that is distinguished from other varieties of the same language by features of phonology, grammar, and vocabulary, and by its use by a group of speakers who are set off from others geographically or socially. This means that we have geographical and social dialects. Social dialects are those that are used by social classes within the society. Such social classes may be marked by their profession, age, sex, colour, peer group, religion and so on. On the other hand, geographical dialects are delineated according to geographical locations.

\section{TONE AND AFFIXES IN AGUATA IGBO}

Let us now look at the behavior of tone in inflectional affixes in Aguata Igbo.

3.1 The $-\mathbf{r v}_{\mathbf{1}} / \mathbf{l v}_{\mathbf{1}}$ suffix- These are affixes that are used in expressing the non past verb forms in the dialects under review.

The $-\mathrm{rv}_{1} / \mathrm{lv}_{1}$ suffix is used in Aguata dialects to express the simple present meaning. For the dialects that use the $1 \mathrm{v}_{1}$ form $/ \mathrm{l} /$ and $/ \mathrm{r} /$ are usually in free variation. The following are examples of the $-\mathrm{rv}_{1} / \mathrm{lv}_{1}$ in the three dialects.

Table 1: Non Past Verb Forms

\begin{tabular}{|c|c|c|c|}
\hline Amaiyi Dialect & Orumba Dialect & Aguata Dialect & Gloss \\
\hline 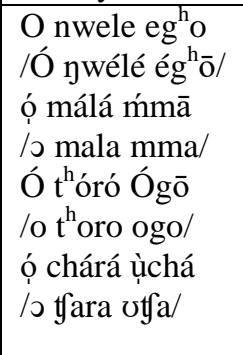 & $\begin{array}{l}\text { O nwere ego } \\
\text { /Ó ywéré égō/ } \\
\text { ó dụ̀ ḿmá } \\
\text { /o dæ mma/ } \\
\text { ó dù̀ ógólógó } \\
\text { / o dæ ogologo } \\
\text { ó dù̀ ò̀chá } \\
\text { /o du stga/ }\end{array}$ & $\begin{array}{l}\text { O nwele ego } \\
\text { /Ó ywélé égō/ } \\
\text { ó málá mmā } \\
\text { /o mala mma/ } \\
\text { Ó tóló ógónógó. } \\
\text { /o tolo ogonogo/ } \\
\text { ó dù òchá. } \\
\text { /o du sta/ }\end{array}$ & $\begin{array}{l}\text { She is beautiful. } \\
\mathrm{He} / \mathrm{she} \text { is tall. }\end{array}$ \\
\hline
\end{tabular}

In the above examples, it is observed that the Amaiyi dialect uses the $-\mathrm{lv}$ and $-\mathrm{rv}$ suffixes interchangeably and that the consonant sounds /t/ in the verb root 'tó' and the voiced velar plosive, /g/ in /égō/ 'money' are aspirated. This is one of the distinguishing characteristics of the Amaiyi dialect from the other Aguata dialects. The Orumba dialect uses the -rv suffix in only one of the examples. In the rest of the cases, 'dụ' -to be, is used to express the present meaning of a good number of stative verbs. The Aguata dialect uses the $-1 v$ suffix for all the examples with the exception of the verb 'dụ̀ ' (ọ cha'). The tone of the -rv/-lv in all the cases is the same as that of the cv stem. However where -dụ is used it is consistently on a low tone.

\subsection{The $\mathrm{rv}_{2} / \mathrm{lv}_{2}$}

The $-\mathrm{rv} /-\mathrm{lv}$ suffix is also used in expressing the simple past in the Aguata dialects. For ease of reference we label the past suffix $\mathrm{rv}_{2} / \mathrm{lv}_{2}$ to differentiate it from the simple present/stative form. The following are examples; 
Table 2: Simple Past Verb Forms

\begin{tabular}{|c|c|c|c|}
\hline Amaiyi Dialect & Orumba Dialect & Aguata Dialect & Gloss \\
\hline ó gàrà áhịá & ó gàrà áhịá & ó gàlà áphịá & $\mathrm{He} / \mathrm{she}$ went to the market \\
\hline Io gara afial & Io gara afial & Io gala a $\beta$ ra/ & \\
\hline ó tara akị & ó tara akị & Ó tàlà ákụ́ & \\
\hline /o tara akı/ & o tara akI/ & /o tara akv/ & He/She ate palm nut \\
\hline Ó chùrù íyí & ó gàrà íyí & ó gàlà íyí & \\
\hline /o turu iji/ & /o gara iji/ & /o gala iji/ & He/She went to fetch water. \\
\hline ó lừrù̀ ògụ̀ & ó lụ̀rù ògụ̀ & ó nụ̀lù̀ ọ̀gù & \\
\hline /o lorv oge & /o loro ogu/ & /o nulv ogv/ & He/She fought \\
\hline
\end{tabular}

In Aguata dialects $-\mathrm{rv}_{2} /-\mathrm{lv}_{2}$ is used to express the simple past meaning. From the examples, Amaiyi and Orumba dialects use $-\mathrm{rv}_{2}$ while Aguata uses $-\mathrm{lv}_{2}$. It is also observed that the cv-stem for the verb ịlù 'to fight' is inù̀ in Aguata dialect. Also, the verb 'to fetch' in both Aguata and Orumba is realized as gala - /gàlà / and gara / gàrà/ respectively but in Amaiyi it is 'chùrù' - /tfuru/. However, the respondents for both Aguata and Orumba hint that in their dialects, the verb 'churu' may be heard among the older speakers. The tone pattern is the same for all the examples; the suffix copies the tone of the cv-stem.

\section{3 $-\mathrm{A} /$ and $-\mathrm{rv}_{3}$ Suffixes}

The imperative verb form for stative verbs a is realized in a number of ways; some express the imperative in the simple cv stem, some do so with open vowel suffix and some with -rv suffix.

The following examples illustrate the above;

Table 3: Imperative Verb Forms for Stative Verbs

\begin{tabular}{|c|c|c|c|}
\hline Amaiyi Dialect & Orumba Dialect & Aguata Dialect & Gloss \\
\hline Dì ńdụ̀ & Dụ̀ ńdụ̀ & Dụ̀ ńdụ̀ & Be alive \\
\hline /di ńdu/ & /du ńdv/ & /du ńdv/ & \\
\hline Hụ̀ ụ̀zò & Hụ̀ ụ̀zò & Hụ̀ ụ̀zò & See \\
\hline /hu uzo/ & /hu vzo/ & hు $v z \supset /$ & \\
\hline Pù̀ árá & Ghọ̀ọ́ árá & Fù̀ árá & Run mad \\
\hline /pu ara/ & /уюо ara/ & /fu ara & \\
\hline
\end{tabular}

In the above examples, all the cv stems are low toned while only the Orumba dialect has one of the verbs using an open vowel suffix - 'ghọọ́'. In the examples that follow, all the dialects use the open vowel suffix to realize the imperative verb form.

Table 4: Imperative Verb Forms

\begin{tabular}{|c|c|c|c|}
\hline Amaiyi Dialect & Orumba Dialect & Aguata Dialect & Gloss \\
\hline Rụ̀ọ́ ớrứ & Rụ̀ọ́ ớrụ́ & Lù̀ọ́ ốlụ́ & Work \\
\hline /ruo orv/ & /roo oro/ & /lvo olv/ & \\
\hline Rìe írí & Rié ńhè & Lié íphè & Eat food \\
\hline /rie iri/ & /rie yhe/ & /lie iße/ & \\
\hline Kwòó ńtụ́ & Kpòó ńtụ́ & Kpòó ńtụ́ & Pack away the ash. \\
\hline /kwoo yto/ & Kpoo yto/ & /kpoo nto/ & \\
\hline
\end{tabular}

The $-\mathrm{rv}_{3} /-\mathrm{v}$ suffix is also used to express imperative in these dialects. The following are the examples;

Table 5: $-\mathrm{rv}_{3} /-\mathrm{v}$ suffix Imperative Verb Forms

\begin{tabular}{|l|l|l|l|}
\hline Amaiyi Dialect & Orumba Dialect & Aguata Dialet & Gloss \\
\hline Kùlú nwá & Kùrú nwátà & Kùlú nwá & Carry the baby \\
/kulu ywa/ & /kuru Đwata/ & /kulu Đwa/ & \\
Kpàrá ákwú́ & Kpàrá ákwú́ & Nwòló ákwú́ & Collect palm-fruits from the stalk \\
/kpara akwo/ & Kpara akwo/ & /gwolo akwo/ & \\
Nò̀ú́ àlà & Túkwùrú àlà & Túkwùlí ànà & Sit down \\
/noro ala/ & /tukwuru ala/ & /tukwuli ana/ & \\
\hline
\end{tabular}

In the above examples, Orumba dialect uses the $-\mathrm{rv}_{3}$ while Aguata uses $-\mathrm{lv}_{3}$ consistently in all the examples but Amaiyi uses both $-\mathrm{rv}_{3}$ and $-\mathrm{lv}_{3}$ interchangeably and there doesn't seem to be any condition for the choice of either -rv or -lv. Also, in Aguata dialect we notice that the suffix does not copy the vowel of the stem 
for the verb 'tukwuli' rather it uses a high front vowel /i// instead of the high back vowel /ú/. The tone of the suffix is such that all the suffixes irrespective of whether it is - rv or -lv are on high tones irrespective of the tone of the $\mathrm{cv}$-stem. The high tone therefore marks imperative in this group of dialects.

\subsection{CV-aux+A/E Prefix}

$\mathrm{A}$ cv-auxilliary and an $\mathrm{A} / \mathrm{E}$ prefix added to the $\mathrm{cv}$ stem are used to express the future tense in these dialects. The following are examples;

Table 6: Future Tense Verb Forms

\begin{tabular}{|c|c|c|c|}
\hline Amaiyi Dialect & Orumba Dialect & Aguata Dialect & Gloss \\
\hline $\begin{array}{l}\text { Ó jè-èjè áhíā } \\
\text { /o dze edze afia/ } \\
\text { Ó jè-èchú íȳi } \\
\text { /o dze etfu iji/ } \\
\text { Ó jè-èri írī } \\
\text { /o dze eri iri/ }\end{array}$ & $\begin{array}{l}\text { Ó jè-èjè áhíā } \\
\text { o dze edze afia/ } \\
\text { Ó jè-èchú íyī } \\
\text { /o dze etfu iji/ } \\
\text { Ó jè-èri ńhè } \\
\text { /o dze eri nfie/ }\end{array}$ & $\begin{array}{l}\text { Ó jè-àgá áphíā } \\
\text { /o dze aga aßıa/ } \\
\text { Ó jè-èchú íȳi } \\
\text { /o dze etfu iji// } \\
\text { Ó jè-èlí íphè } \\
\text { /o dze eli iße/ }\end{array}$ & $\begin{array}{l}\text { He/she will go to the market } \\
\text { He/she will go to fetch water } \\
\text { He/she will eat food }\end{array}$ \\
\hline
\end{tabular}

In the above examples, the auxiliary and the prefix (participial marker) are consistently on low tone for all the dialects.

\subsection{A+ CV + E + la}

Affixes are also used in the realization of the perfective verb form in Aguata group of dialects. These are the open vowel prefix ' $A$ ', the open vowel suffix ' $E$ ' (each harmonizing with the vowel of the cv stem) and the perfective marker -la thus; A+CV + E + la. Examples;

Table 7: Perfective Verb Forms

\begin{tabular}{|c|c|c|c|}
\hline Amaiyi Dialect & Orumba Dialect & Aguata Dialect & Gloss \\
\hline $\begin{array}{l}\text { Ńgó́zí èlíéné ílí } \\
\text { /ggozi eliene ili// }\end{array}$ & $\begin{array}{l}\text { Ńgó́zí èríélé ńhe } \\
\text { /ngozi eriele Đhe/ }\end{array}$ & $\begin{array}{l}\text { Ńgó́zí èlíéné íphè } \\
\text { /ngozi eliene iße/ }\end{array}$ & Ngozi has eaten food \\
\hline $\begin{array}{l}\text { Òbí èjéwáláná áhíá } \\
\text { /obi èdzewalana } \\
\text { ahja/ }\end{array}$ & $\begin{array}{l}\text { Òbí èjéwágwélé áhíá } \\
\text { /Obi edzewagwele } \\
\text { afja/ }\end{array}$ & $\begin{array}{l}\text { Òbú àgááná áphịá } \\
\text { /obu agaana afja/ }\end{array}$ & $\begin{array}{l}\text { Obi has gone to the } \\
\text { market }\end{array}$ \\
\hline $\begin{array}{l}\text { Òkéké ànwứọ́ná } \\
\text { /Okeke ałwơna/ }\end{array}$ & $\begin{array}{l}\text { Òkéké ànwứólé } \\
\text { /Okeeke aywoole/ }\end{array}$ & $\begin{array}{l}\text { Òkéké ànwừọ́ná } \\
\text { /okeeke aywoona/ }\end{array}$ & Okeke has died \\
\hline $\begin{array}{l}\text { Òkóòlì àrúgwóné ụ́lụ́ò } \\
\text { /Okooli arogwone oloj/ }\end{array}$ & $\begin{array}{l}\text { Òkóòlì àlứólé ụ́lò } \\
\text { /Okooli aluole ol๖/ }\end{array}$ & $\begin{array}{l}\text { Òkóòlị àlụ́ọ́ná ứnò } \\
\text { /Okooli aloona } \\
\text { ons/ }\end{array}$ & Okoli has built a house \\
\hline
\end{tabular}

In the examples above, the tone of the prefix is always low in all the dialects. The cv stem, the vowel suffix as well as the -la perfective marker in all the dialects are on high tone. There are some variations in the suffixes. The Aguata and Amaiyi dialects have the -la suffix as -na or -ne in harmony with the vowel of the cv stem. The Orumba dialect has the perfective marker -la as --le in all the environments regardless of the rule of vowel harmony. The verb 'iga' - to go has a number of realizations in the perfective aspect in the dialects; Orumba has it as 'èjéwágwélé', Amaiyi has it as 'èjéwáláná' and Aguata has it as 'àgáná'. The above examples in Table 7 are tenable to sentences with proper nouns as their subject NP. However, in other constructions with pronominal NPs where the pronoun is a vowel, the prefix is deleted while the pronominal NP is always on a high tone. The following exemplify this fact;

Table 8: Perfective Verb Forms of Verbs in Sentences with Pronominal NPs

\begin{tabular}{|c|c|c|c|}
\hline Amaiyi Dialect & Orumba Dialect & Aguata Dialect & English Translation \\
\hline $\begin{array}{l}\text { Ó líéné ílí } \\
\text { /o liene ili// }\end{array}$ & $\begin{array}{l}\text { Ó ríélé ńhe } \\
\text { /o riele yhe/ }\end{array}$ & $\begin{array}{l}\text { O líéné íphè } \\
\text { /o liene iфe/ }\end{array}$ & He has eaten \\
\hline $\begin{array}{l}\text { Ó jéwáláná áhíá } \\
\text { /Ó dzewalana ahja/ }\end{array}$ & $\begin{array}{l}\text { Ó jéwágwélé áhíá } \\
\text { /o dzewagwele afija/ }\end{array}$ & $\begin{array}{l}\text { ó gáná áphịá } \\
\text { I o gana aфja/ }\end{array}$ & She has gone to the market \\
\hline ọ nwứọ́ná & ọ́ nwứọ́lé & ọ́ ọ́nwụọna & He has died \\
\hline
\end{tabular}




\begin{tabular}{|c|c|c|c|}
\hline / э nwoona/ & / o ywoole/ & /s ywoona/ & \\
\hline $\begin{array}{l}\text { ó rứgwóné ụ́lứọ̀ } \\
\text { / o rogwone olơ/ }\end{array}$ & $\begin{array}{l}\text { ó lứóolé ứlò̀ } \\
\text { /o loole ol๖/ }\end{array}$ & $\begin{array}{l}\text { ó lứọ́ná ứnò } \\
\text { / o lơna ono/ }\end{array}$ & He has built a house \\
\hline
\end{tabular}

3.6 -hú - The Negative Marker

In Aguata dialects, the suffix -hú which the vowel reduplicates the vowel of the cv stem is consistently used to mark negation in the dialects.

Table 9: Verb Forms for Negation

\begin{tabular}{|c|c|c|c|}
\hline Amaiyi Dialect & Orumba Dialect & Aguata Dialect & English Translation \\
\hline $\begin{array}{l}\text { Ọ dứhứ ńdụ́ } \\
\text { /o dohu ydv/ }\end{array}$ & $\begin{array}{l}\text { O dụ́hứ ńdụ́ } \\
\text { Io dohu ydo/ }\end{array}$ & $\begin{array}{l}\text { Ọ dụ́hụ́ ńdứ } \\
\text { /o dohu ydo/ }\end{array}$ & He is not alive \\
\hline $\begin{array}{l}\text { Ò vúhú ívú } \\
\text { /o vuhu ivu/ }\end{array}$ & $\begin{array}{l}\text { Ò vúhú ívú } \\
\text { /o vuhu ivu/ }\end{array}$ & $\begin{array}{l}\text { Ò vúhú ívú } \\
\text { /o vuhu ivu/ }\end{array}$ & He is not carrying a load \\
\hline $\begin{array}{l}\text { Ó jíhí égō } \\
\text { /odzihi ego/ }\end{array}$ & $\begin{array}{l}\text { òjíhú égō } \\
\text { /o ḑihi ego/ }\end{array}$ & $\begin{array}{l}\text { Ó jíhí égō } \\
\text { /o ḑihi ego/ }\end{array}$ & $\mathrm{He}$ is not rich \\
\hline $\begin{array}{l}\text { ó wứhụ́ nwókē } \\
\text { /o wohu nwoke/ }\end{array}$ & $\begin{array}{l}\text { ó ghứhứ nwókē } \\
\text { /o yohư nwoke/ }\end{array}$ & $\begin{array}{l}\text { ó wứhứ nwókē } \\
\text { / o wohu nwoke }\end{array}$ & $\mathrm{He}$ is not a man \\
\hline
\end{tabular}

In all the dialects as shown above, the cv stem and -hu suffix are on high tone. Also, for sentences with proper nouns as subject NP, the verb form has a vowel prefix which harmonizes with the vowel of the cv stem as shown below.

Table 10: Negative Verb Forms in Sentences with Proper Nouns as NP

\begin{tabular}{|c|c|c|c|}
\hline Amaiyi Dialect & Orumba Dialect & Aguata Dialect & English Translation \\
\hline Òkólì adụ́hụ́ ńdụ́ & Òkólì adứhụ́ ńdụ́ & Òkólì adụ́hụ́ ńdú & Okoli is not alive \\
\hline /Okooli advhu ydø/ & /Okooli advhu ydø/ & /okoli aduhø ydø/ & \\
\hline $\begin{array}{l}\text { Ńgó́zí vúhú ívú } \\
\text { /ngozi evuhu ivu/ }\end{array}$ & $\begin{array}{l}\text { Ńgó́zí evúhú ívú } \\
\text { /ngozi evuhu ivu/ }\end{array}$ & $\begin{array}{l}\text { Ńgózí evúhú ívú } \\
\text { /ngozi evuhu ivu/ }\end{array}$ & Ngozi is not carrying a load \\
\hline $\begin{array}{l}\text { Mádụká éjíhí égō } \\
\text { /madoka e dzihi ego/ }\end{array}$ & $\begin{array}{l}\text { Mádùkà éjíhú égō } \\
\text { /madoka e ḑiho ego/ }\end{array}$ & $\begin{array}{l}\text { Mádụká ejihi egō } \\
\text { /madoka edzihi ego/ }\end{array}$ & Maduka is not rich \\
\hline
\end{tabular}

3.7 The prefix A- + stem + the suffix -LA or shi (The Negative Imperative markers)

The vowel prefix A- and the suffixes LA/NA or shi are used to mark the negative imperative in the dialects of Aguata. The following are examples:

Table 11: Negative Imperative Verb Forms

\begin{tabular}{|c|c|c|c|}
\hline Amaiyi Dialect & Orumba Dialect & Aguata Dialect & English Translation \\
\hline $\begin{array}{l}\text { Éríshí írí } \\
\text { /erifi iri/ }\end{array}$ & $\begin{array}{l}\text { Éríshí ńhè } \\
\text { /erifi nhe/ }\end{array}$ & $\begin{array}{l}\text { Élíné íphé } \\
\text { /eline iфe/ }\end{array}$ & Don’t eat \\
\hline $\begin{array}{l}\text { Ébéné ákwá } \\
\text { /ebene akwa/ }\end{array}$ & $\begin{array}{l}\text { Ébéshí ákwá } \\
\text { /ebefi akwa/ }\end{array}$ & $\begin{array}{l}\text { Ébéné ákwá } \\
\text { /ebene akwa/ }\end{array}$ & Don't cry \\
\hline $\begin{array}{l}\text { Ékwúshí ụ́kà } \\
\text { /ekwuJi oka/ }\end{array}$ & $\begin{array}{l}\text { Ékwúshí ókwú } \\
\text { /ekwufi okwu/ }\end{array}$ & $\begin{array}{l}\text { Ékwúné ókwú } \\
\text { /ekwune okwu/ }\end{array}$ & Don't talk \\
\hline $\begin{array}{l}\text { Ágáná áhíá } \\
\text { /agana ahja// }\end{array}$ & $\begin{array}{l}\text { Éjélé áhíá } \\
\text { /edzele ahja/ }\end{array}$ & $\begin{array}{l}\text { Éjéné áphíá } \\
\text { /edzene aфja/ }\end{array}$ & Don't go to the market \\
\hline
\end{tabular}

The suffixes and the prefixes are on high tone in all the dialects. The cv stems are high toned except for the tone class one verbs (Nwachukwu 1984 classification) which have their $\mathrm{cv}$ stem and suffixes on low tone. For example, the verb nwụ́ 'to die' is realized as 'ánwụ̀nà' with '-'-na' copying the tone of the cv vowel. 
Table 12: Negative Verb Forms for Tone Class One Verbs

\begin{tabular}{|c|c|c|c|}
\hline Amaiyi Dialect & Orumba Dialect & Aguata Dialect & English Translation \\
\hline $\begin{array}{l}\text { Ò jéhé éjé áhíá } \\
\text { /o dzehe edze ahja/ }\end{array}$ & $\begin{array}{l}\text { ò jéhú éjé áhíá } \\
\text { /o dzehu edze ahja/ }\end{array}$ & $\begin{array}{l}\text { ò jéhé ágá áphíá } \\
\text { /o dzehe aga aфja/ }\end{array}$ & He will not go to the market \\
\hline $\begin{array}{l}\text { Ńgọ́zí jéhé échú iyi } \\
\text { /ngozi edzehe etfu iji/ }\end{array}$ & $\begin{array}{l}\text { Ńgọ́zí jéhé échú íyí } \\
\text { /ngozi edzehe etfu iji/ }\end{array}$ & $\begin{array}{l}\text { Ńgọ́zí éjéhé échú iyi } \\
\text { /ngozi edzehe etfu iji/ }\end{array}$ & $\begin{array}{l}\text { Ngozi will not go to fetch } \\
\text { water }\end{array}$ \\
\hline $\begin{array}{l}\text { Òkéké éjéhé ázà ụlụ̀ọ } \\
\text { /okeeke edzehe aza } \\
\text { oloo/ }\end{array}$ & $\begin{array}{l}\text { Òkéké éjéhú ázà ụ́lò̀ } \\
\text { /okeeke eḑehu aza } \\
\text { olo/ }\end{array}$ & $\begin{array}{l}\text { Òkéké éjéhé ázà ụ́nò̀ } \\
\text { /okeeke edzehe aza olo/ }\end{array}$ & $\begin{array}{l}\text { Okeke will not sweep the } \\
\text { house }\end{array}$ \\
\hline $\begin{array}{l}\text { ò jéhé érí írí } \\
\text { /odzehe eri iri/ }\end{array}$ & $\begin{array}{l}\text { ò jéhụu érí ńhè } \\
\text { /o ḑeho eri nhe/ }\end{array}$ & $\begin{array}{l}\text { ò jéhé élí íphè } \\
\text { /o ḑehe eli iфe/ }\end{array}$ & He will not eat \\
\hline
\end{tabular}

Aguata and Amaiyi dialects use -he/hu negative marker in all environments regardless the rule of vowel harmony and so does Orumba dialect in using -hu suffix. It should be noted that the Aguata dialect has the verb to eat as ili, while the rest of the dialects have it as "iri". Thus Aguata dialect uses the alveolar lateral /1/ in place of the post alveolar trill /r/ while Amaiyi has the word for 'food' nri as ' $\mathrm{i} \square \mathrm{i}$ '. It is also observed that the sentences with proper nouns as their subject NPs have a vowel prefix in the auxiliary verb 'je' - to go. These prefixes are on high tones in all the dialects.

\section{8 -HU Suffix (The simple past aspect marker)}

The negative simple past aspect is expressed in Aguata dialects by the suffix -hu which sometimes reduplicates the vowel of the cv stem or is used as -hu irrespective of the vowel in the cv stem. The following are examples;

Table 13: Simple Past Negative Verb Forms

\begin{tabular}{|c|c|c|c|}
\hline Amaiyi Dialect & Orumba Dialect & Aguata Dialect & English Translation \\
\hline Ò jéhé áhía & ò jéhụ́ áhíá & ò jéhé áphíá & He did not go to the market \\
\hline /o dzehe ahja/ & /o dzehø ahja/ & /o dzehe aфja/ & \\
\hline ò ríhí írí & ò ríhụ́ ńhè & ò líhí íphé & \\
\hline /o rihi iri/ & /oriho nhe/ & /o lihi iфe/ & He did not eat \\
\hline ò táhá ánụ́ & ò ríhụ́ ánứ & ò táhá ánứ & \\
\hline / o taha ano/ & /o rího ano/ & Io taha ano/ & He did not eat meat \\
\hline $\begin{array}{l}\text { ò rứhứ ốrú́ } \\
\text { /o roho orv/ }\end{array}$ & $\begin{array}{l}\text { ò rứhứ ốrụ́ } \\
\text { /o roho oro/ }\end{array}$ & $\begin{array}{l}\text { ò lụhụ ọlụ } \\
\text { /o luhu olv/ }\end{array}$ & He did not work \\
\hline
\end{tabular}

In all the examples, the cv stem and the suffixes are on a high tone in all the dialects. Orumba dialect however uses -hu negative suffix consistently for all verbs. The negative perfective verb form is realized in Aguata dialects by using either the -be or -we and a harmonizing- hE suffix plus the cv stem of the particular verb in question.

Examples:

Table 14: Negative Perfective Verb Forms

\begin{tabular}{|c|c|c|c|}
\hline Amaiyi Dialect & Orumba Dialect & Aguata Dialect & English Translation \\
\hline Ò jébèhè áhíá & ò jéwèhụ̀ áhíá & ò jébèhè áphíá & He had not gone to the market \\
\hline /o dzebehe ahja/ & /o dzeweho ahja/ & /o dzebehe aфja/ & \\
\hline ò ríbèhè írí & ò ríwèhụ̀ ńhé & ò líbèhè íphé & He had not eaten \\
\hline /o ribehe iri/ & /o riweho nhe/ & /o libehe iфe/ & \\
\hline $\begin{array}{l}\text { ò tábèhe ánụ } \\
\text { /o tabehe anv/ }\end{array}$ & $\begin{array}{l}\text { ò riwèhù̀ ánú́ } \\
\text { /o riwehv anv/ }\end{array}$ & $\begin{array}{l}\text { ò tábèhè ánú } \\
\text { / } 0 \text { tabehe ano/ }\end{array}$ & He had not eaten meat \\
\hline
\end{tabular}

The cv stem is always on a high tone in all the dialects while all the suffixes are on low tone. It is observed that in all the dialects under study, the negative perfective aspect could also mean that the actions so described have never taken place. Thus, the sentence 'o ribehe iri' could also mean 'He has never eaten food." From the discussions, the Aguata dialects make use of a number of suffixes to denote negation. These include the '-he' suffix for simple present aspect, 'le, he or shi' for the imperative aspect, 'jehu' for future aspect, 'hu' for simple past and 'wehu' or 'behu' for the perfective aspect verb forms.

\section{SUMMARY AND CONCLUSION}


In Aguata dialects, some of the affixes vary considerably. Table 15 on page 11 shows the variations in the affixes of Aguata dialects as outlined in this work. There are not only variations in the forms of the affixes but also variations in tone patterns within the dialects. For example, in the sentence, 'Ruo oru' - 'Work!' Orumba and Amaiyi dialects have the tone pattern - LHHH (low high high high) while Orumba dialect has it as 'Luọ olu' - HHHH (high high high high). Also the sentence 'He/she is beautiful', Amaiyi and Aguata have it as 'ó málá ḿmā' (HHHHS) while Orumba has it as 'ó dụ̀ ḿmá' (HLHH). It should also be noted that while the other two dialects use the high tone -rv/-lv suffix for this aspect, Orumba uses -the low tone 'dừ'. There are also variations in the form of the verbs themselves. For example, the verb 'di' - 'to be' in standard Igbo is realized differently in the dialects under study. It is either 'wụ̀' or 'gụ̀' in the Aguata dialects. They thus replace the voiced biblical plosive /b/ with either the labio-velar approximant /w/ or an aspirated voiced velar plosive /g/ and the high front vowel /i/ with the high back vowel / $/$. Sometimes in Aguata dialects, a verb which is different from that of the other dialects is used in the same environment to express equivalent meanings. For example, we have 'ó málá ḿmā' in Amaiyi and Aguata and 'ó dụ̀ ḿmá' in Orumba dialect, both sentences meaning 'He/she is beautiful'. In Table 15 below, we present a summary of the affixes as discussed in this work.

Table 15: Summary of Affixes Discussed

\begin{tabular}{|c|c|c|c|c|c|c|}
\hline & $\begin{array}{l}\text { Amaiyi } \\
\text { Dialect }\end{array}$ & & $\begin{array}{l}\text { Orumba } \\
\text { Dialect }\end{array}$ & & $\begin{array}{l}\text { Aguata } \\
\text { Dialect }\end{array}$ & \\
\hline & Affirmative & Negative & Affirmative & Negative & Affirmative & Negative \\
\hline $\begin{array}{l}\text { The stative } \\
\text { suffix }\end{array}$ & $\begin{array}{l}\mathrm{lv}_{1} / \mathrm{rv}_{1} \text { e.g } \\
\text { (-le/la/- } \\
\text { re/-ra } \\
\text { lo/lọ/ro/rọ }\end{array}$ & $\begin{array}{l}\text {-hu harmonizes } \\
\text { with the vowel of } \\
\text { cv stem }\end{array}$ & $\begin{array}{l}\text {-rV } \mathrm{V}_{1} \mathrm{e} . \mathrm{g} \\
\text { (-re/-ra/- } \\
\text { ro/-rọ/ }\end{array}$ & -hu & $\begin{array}{l}-\mathrm{lv}_{1} \text { e.g. } \\
(-\mathrm{le} /-\mathrm{la} /-\mathrm{lo} /- \\
\text { lọ) }\end{array}$ & $\begin{array}{l}\text {-hu harmonizes } \\
\text { with the vowel of } \\
\text { the cv stem. }\end{array}$ \\
\hline $\begin{array}{l}\text { Imperative } \\
\text { suffix }\end{array}$ & $-\mathrm{A}(\mathrm{a} / \mathrm{e} / \mathrm{o} / \mathrm{o})$ & $\begin{array}{l}\mathrm{A}+ \\
\text {-ne/-shi }\end{array}$ & -A(a/e/o/o ) & $\begin{array}{l}\mathrm{A}+\mathrm{le} /- \\
\text { shi }\end{array}$ & $-a(a / e / o / o)$ & A +-na/ne \\
\hline $\begin{array}{l}\text { Simple } \\
\text { Past suffix }\end{array}$ & $\begin{array}{l}\text {-rV e.g } \\
\text { (-re/ra/-ro) }\end{array}$ & $\begin{array}{l}\text {-hu re-duplicates } \\
\text { the vowel of the } \\
\text { cv stem }\end{array}$ & $\begin{array}{l}\text {-rV e.g. } \\
\text { (-re/-ra/-ro) }\end{array}$ & -hu & $\begin{array}{l}-1 \mathrm{~V}_{2} \text { e.g. } \\
(-\mathrm{le} /-\mathrm{la} /-\mathrm{lo} /\end{array}$ & $\begin{array}{l}\text {-hu redu-plicates } \\
\text { the vowel of the } \\
\text { cv stem }\end{array}$ \\
\hline $\begin{array}{l}\text { Perfective } \\
\text { Suffix }\end{array}$ & $\begin{array}{l}\text { - ne/ na / } \\
\text { na/walana } \\
\text { /gwone }\end{array}$ & -behe & $\begin{array}{l}\text { - le/ } \\
\text {-wagwele }\end{array}$ & -wehu & - ne/- na & -behe \\
\hline
\end{tabular}

As could be seen from the discussions, the inflectional affixes vary from one dialect to another. The various affixes found in the dialects of Aguata vary within these dialects. However, it should also be noted that the differences are still within the range that makes for mutual intelligibility hence they are dialects of the same language. Yet, it goes to confirm the fact that even as they belong to the same dialect cluster according to Ikekeonwu (1987) classification, they still exhibit peculiar differences which only a more detailed observation would reveal. This is contrary to the general notion that the whole of Aguata area speak the same dialect.

\section{REFERENCES}

[1]. Comrie, B. (1978). Aspects. Cambridge: Cambridge University Press.

[2]. Emenanjo, E. N. (1978). Elements of Modern Igbo Grammar. Ibadan: Oxford University Press.

[3]. Emenanjo, E. N. (1983). "The Status of the Auxiliary" in P. A. Nwachukwu (ed.) Readings on Igbo Verb. Onitsha: Africana FEB Publishers Limited.

[4]. Ikeaka, E. C. (1985). "Affixal Variation in Igbo Dialects of Aguata Local Government Area of Anambra State. B. A. Long Essay submitted to the Department of Linguisticsand Nigerian Languages, University of Nigeria, Nsukka.

[5]. Matthews, P. H. (1979). Morphology, an Introductory Survey. Cambridge: Cambrdge University Press.

[6]. Ndimele, O. M. (1999). Morphology and Syntax. Port Harcourt. Emhai Press.

[7]. Nwachukwu, P.A. (1983). Towards a Literary Igbo Standard. London: Routledge and Kegan.

[8]. Nwachukwu, P. A. (1995). Tone in Igbo Syntax. Nsukka: Igbo Language Association.

[9]. Nwankwegu, J. N. (2013). Fundamentals of Morphology. Enugu: De Envoy Media.

[10]. Nwaozuzu, G.I.(2008). Dialects of Igbo Language. Nsukka :University of Nigeria Press Ltd.

[11]. Yip, M. (2007). "Tone". de Lacy (ed) Cambridge Handbook of Phonology.229-251

[12]. Dialect- (n.d.). Dictionary.com Unabridged. Retrieved October 06, 2013, from Dictionary.com website: http://dictionary.reference.com/browse/dialect 